\title{
PELAKSANAAN PEMBELAJARAN KOOPERATIF TIPE TWO STAY TWO STRAY UNTUK MENINGKATKAN HASIL BELAJAR PENDIDIKAN AGAMA KRISTEN KELAS IV SDN BARATAJAYA SURABAYA
}

\author{
YUSAK \\ SDN Baratajaya Surabaya \\ yusaktrizoe228@gmail.com
}

\begin{abstract}
This research was motivated by the low learning outcomes of Christian Religious Education with a grade average of 61. Meanwhile, the minimum completeness criteria for Christian Religious Education were 75. Among the 9 students, only 3 students achieved minimum completeness criteria with $44 \%$ classical completeness. This research is a classroom action research which aims to improve the learning outcomes of the fourth grade students of SDN Baratajaya Surabaya by applying the Two StayTwo Stray Technique Cooperative model. Data collection instruments in this thesis are teacher and student activity sheets and learning outcomes. This study presents the learning outcomes obtained by an average learning outcome before action 61 increases to 66 in cycle I. In cycle II increases to an average of 82. Teacher activity in the first cycle of the first meeting the percentage obtained is 2.85 with a percentage of $66 \%$ including in the good category, in the second cycle was 3.33 in the very good category with a percentage of $88 \%$. This shows that there is an increase in teacher skills by 0.48 with a percentage of $48 \%$. While the average student activity in the first cycle was 3.09 with a percentage of $66 \%$, in the second cycle it was 3.17 with a percentage of $88 \%$ so there was a fairly good increase, namely 0.08 with a percentage of $8 \%$. This shows that an increase in teacher skills and student activity affects the increase in student learning outcomes so that the quality of Christian Religious Education learning increases.
\end{abstract}

Keywords : Two Stay-Two Stray Cooperative Techniques, Learning Outcomes of Christian Religious Education

\section{PENDAHULUAN}

Belajar mengajar pada dasarnya adalah interaksi atau hubungan timbal balik antara guru dan siswa dalam situasi pendidikan. Oleh karena itu, guru didalam mengajar dituntut kesabaran, keuletan dan sikap terbuka disamping kemampuan dalam situasi belajar mengajar yang lebih aktif dan siswa juga dituntut adanya semangat dan dorongan. Penggunaan metode konvensional pada saat pembelajaran berlangsung sudah tidak relevan untuk mencapai kompetensi ranah kognitif dan afektif. Hal ini dikarenakan metode konvensional hanya dapat mengembangkan ranah kognitif saja, sedangkan afektif dan psikomotor tidak tercapai.

Betapa pentingnya sebuah model pembelajaran dalam proses pembelajaran supaya bisa berhasil. Model pembelajaran ini dibutuhkan juga dalam kelas Pendidikan Agama Kristen di Sekolah Dasar. Pendidikan Agama Kristen pada dasarnya bertujuan agar peserta didik menjadi anak yang beriman dan bertaqwa terhadap Tuhan Yang Maha Esa, dan berbudi pekerti luhur.

Tujuan ini hanya bisa dicapai jika model pembelajaran yang digunakan mampu merangsang peserta didik terlibat aktif dalam proses pembelajaran. Keaktifan anak-anak dalam kelas menjadi salah satu faktor penting keberhasilan pembelajaran sehingga proses pembelajaran semakin hidup dan menyenangkan.

Sekolah Dasar adalah lembaga pemerintah di tingkat dasar yang meletakan pondasi iman bagi siswa Kristen sehingga dapat mengenal dan meneladani tokoh sentral kehidupan segala abad yaitu Tuhan Yesus. Ketika orang tua mu-rid dan pihak sekolah bekerja sama men-didik peserta didik dengan benar maka pertumbuhan iman anak akan terbangun dengan kuat. Kita harus sadar bahwa pertumbuhan peserta didik selain mendapat materi dan penerapan di sekolah, keluarga juga memiliki peran penting. Oleh sebab itu Pendidikan Agama Kristen di jaman milenial ini 
menekankan pendidikan karakter dan budi pekerti sebagai salah satu model pembelajaran yang menjadi jawaban bagi masa depan generasi. Keberhasilan tersebut terwujud apabila Pendidikan Agama Kristen di sekolah dasar dilaksanakan sebaik-baiknya yang didukung dengan metode yang tepat maupun cara pembelajaran yang kreatif dan efisien yang juga harus ditopang oleh keluarga.

Perhatikan kutipan Ulangan 6:4-9 berikut,

Dengarlah, hai orang Israel: TUHAN itu Allah kita, TUHAN itu esa! Kasihilah TUHAN, Allahmu, dengan segenap hatimu dan dengan segenap jiwamu dan dengan segenap kekuatanmu. Apa yang kuperintahkan kepadamu pada hari ini haruslah engkau perhatikan, haruslah engkau mengajarkannya berulang-ulang kepada anak-anakmu dan membicarakannya apabila engkau duduk di rumahmu, apabila engkau sedang dalam perjalanan, apabila engkau berbaring dan apabila eng-kau bangun. Haruslah juga engkau mengikatkannya sebagai tanda pada tanganmu dan haruslah itu menjadi lambang di dahimu, dan haruslah engkau menuliskannya pada tiang pintu rumahmu dan pada pintu gerbangmu.

Kutipan diatas nats diatas dikenal dengan "Shema" atau perintah Allah yang wajib dijalankan oleh umat Israel. Perintah ini menjadi tanda persekutuan yang intim antara umat dengan Allah sebagai prioritas utama. Perintah ini harus tertanam dalam hati orang Israel, tertanam dalam hati anak-anak Israel, harus menjadi bagian hidup sehari-hari mereka, harus menjadi identitas pribadi mereka, dan menjadi identitas keluarga serta masyarakat Israel. Tidak ada satu bagian pun dalam kehidupan orang Kristen yang terlepas dari relasi mereka yang penuh kasih kepada Allah.

Model pembelajaran kooperatif teknik Two Stay Two Stray dikembang- kan oleh Spencer Kagan pada tahun 1992. Model pembelajaran kooperatif teknik Two Stay Two Stray merupakan suatu teknik yang memberi kesempatan kepada kelompok untuk membagi hasil dan informasi dengan kelompok lain. Hal ini dilakukan dengan cara saling mengunjungi atau bertamu antar kelompok untuk berbagi informasi. Teknik ini bisa digunakan mata pelajaran PAK dan juga bisa untuk semua tingkatan usia anak didik (Sugianto. 2010 : 54). Teknik ini sangat cocok diterapkan dalam pembelajaran Pendidikan Agama Kristen karena teknik ini menuntut siswa untuk berkomunikasi, bekerja sama dan bertanggung jawab dalam kelompok karena setiap siswa mempunyai tugas dan tanggung jawab masing-masing.

Adapun manfaat dari penelitian ini adalah untuk meningkatkan kualitas pembelajaran Pendidikan Agama Kristen dimana siswa lebih aktif, kreatif, terampil, serta pembelajaran menjadi bermakna sehingga aspek kognitif, afektif, dan psikomotorik siswa dapat berkembang dengan optimal.

\section{KAJIAN PUSTAKA Belajar dan Pembelajaran}

Kata "belajar" menurut kamus bahasa Indonesia adalah berusaha memperoleh kepandaian atau ilmu, berlatih, berubah tingkah laku atau tanggapan yang disebabkan oleh pengalaman. Sedangkan belajar menurut para ahli dalam Rifa'i RC dan Tri anni (2009:82) merangkum pendapat Gage dan Barliner (1983) menyatakan bahwa belajar merupakan proses dimana suatu organisme mengubah perilakunya karena hasil dari pengalaman. Morgan et. al. (1986) menyatakan bahwa belajar merupakan perubahan relatif permanen yang terjadi karena hasil dari praktik atau pengalaman. Slavin (1994) menyatakan bahwa belajar merupakan perubahan individu yang disebabkan oleh pengalaman. sedangkan Gagne (1977) menyatakan bahwa belajar merupakan perubahan 
PELAKSANAAN PEMBELAJARAN KOOPERATIF TIPE

TWO STAY TWO STRAY UNTUK MENINGKATKAN

HASIL BELAJAR PENDIDIKAN AGAMA KRISTEN

KELAS IV SDN BARATAJAYA SURABAYA

disposisi atau kecakapan manusia yang berlangsung selama periode waktu tertentu dan perubahan perilaku itu tidak berasal dari proses pertumbuhan.

Belajar merupakan suatu proses perubahan tingkah laku sebagai hasil dari pengalaman individu dalam berinteraksi dengan lingkungannya. Konsep dalam belajar mengandung tiga unsur yaitu, perubahan tingkah laku, berdasarkan pengalaman, dan bersifat permanen. Belajar dalam konteks luas menampilkan serangkaian aktivitas seperti membaca, mengamati, mendengar, meniru dan lainnya sebagai hasil dari pengalaman.

Adapun perubahan tingkah laku dalam pengertian belajar memiliki ciriciri seperti, perubahan terjadi secara sadar, perubahan dalam belajar bersifat terus menerus dan fungsional, perubahan dalam belajar bersifat positif dan aktif, perubahan dalam belajar tidak bersifat sementara, perubahan dalam belajar bertujuan dan terarah, perubahan mencakup seluruh aspek tingkah laku. (Slameto : 2003 ).

Gagne (1981) dalam Rifa'i, RC dan Tri Anni (2009:191) menyatakan bahwa pembelajaran merupakan serangkaian peristiwa eksternal peserta didik yang dirancang untuk mendukung proses internal belajar. Menurut Briggs (1992) dalam Rifa'i RC dan Tri anni (2009:191) Pembelajaran adalah seperangkat peristiwa yang mempengaruhi peserta didik sedemikian rupa sehingga peserta didik itu memperoleh kemudahan. Seperangkat peristiwa itu membangun suatu pembelajaran yang bersifat internal jika peserta didik melakukan self intruction dan bersifat eksternal jika bersumber dari pendidik.

Pembelajaran adalah proses interaksi peserta didik dengan pendidik dan sumber belajar pada suatu lingkungan belajar seperti tertuang dalam UU RI No. 20 : 2003, bab I Pasal I ayat 20. Menurut Mulyasa (2006:117) pembela- jaran merupakan aktualisasi kurikulum yang menuntut keaktifan guru dalam menciptakan dan menumbuhkan kegiatan peserta didik sesuai dengan rencana yang telah diprogramkan.

\section{Pengertian Pendidikan Agama Kris- ten.}

Pendidikan Agama Kristen didasarkan pada Amanat Agung dalam Matius 28:18-20 dikatakan,

"Kepada-Ku telah diberikan segala kuasa di sorga dan di bumi. Karena itu pergilah, jadikanlah semua bangsa murid$\mathrm{Ku}$ dan baptislah mereka dalam nama Bapa dan Anak dan Roh Kudus, dan ajarlah mereka melakukan segala sesuatu yang telah Kuperintahkan kepadamu.

Pendidikan Agama Kristen tidak hanya dikerjakan oleh manusia tetapi lebih menitik beratkan pada pribadi Allah. Keterlibatan-Nya mutlak diperlukan karena Pendidikan Agama Kristen bukan hanya mendidik secara ilmu pengetahuan, namun lebih menekankan pembentuk karakter peserta didik.

Paulus L. Kristianto mengutip pernyataan Werner C. Graendorf (1976) menjelaskan bahwa,

Pendidikan Agama Kristen adalah proses pengajaran dan pembelajaran yang berdasarkan Alkitab, berpusat pada Kristus, dan bergantung pada kuasa Roh $\mathrm{Ku}-$ dus, yang membimbing setiap pribadi pada semua tingkat pada pertumbuhan, melalui pengajaran masa kini kearah pengenalan dan pengalaman rencana dan kehendak Allah melalui Kristus dalam setiap aspek kehidupan, dan memperlengkapi mereka bagi pelayanan yang efektif, yang berpusat pada Kristus sang Guru Agung dan perintah yang mendewasakan para murid.

(Paulus L. Kristianto: 2006). 
Dr. Saur Hasugian berpendapat, pendidikan agama Kristen adalah salah satu usaha yang membawa seseorang dari suatu keadaan kepada keadaan yang baru untuk mengembangkan serta mendewasakan diri dalam sikap yang lebih bertanggung jawab dalam keluarga dan lingkungan masyarakat. Pendidikan Kristen membawa seseorang sehingga dewasa di dalam imannya yang dipimpin oleh Roh Kudus. Pendidikan Agama Kristen bersumber pada Kristus dan berorientasi Kristiani.

Pendidikan Kristen memiliki pengertian yang luas dan bergantung pada konteksnya. Robert W. Pazmino mengatakan bahwa pendidikan Kristen merupakan usaha sengaja dan sistematis ditopang oleh upaya rohani dan manusiawi untuk mentransmisikan pengetahuan nilai-nilai, sikap-sikap, keterampilan-keterampilan, dan tingkah laku yang bersesuaian atau konsisten dengan iman Kristen dalam rangka mengupayakan perubahan pembaharuan dan reformasi pribadi kelompok bahkan struktur oleh kua-sa Roh Kudus sehingga peserta didik hidup sesuai dengan kehendak Allah seba-gaimana dinyatakan oleh Alkitab dalam Yesus Kristus. ( B.S. Sidjabat: 2000).

Pendidikan agama Kristen merupakan pendidikan dasar yang harus diterima mulai sejak dini. Tujuannya supaya setiap orang percaya bertumbuh, berkembang dan bertanggung jawab dalam panggilannya di tengah masyarakat. Pendidikan agama Kristen juga memberikan motivasi iman yang didasarkan atas kitab suci. Pendidikan Kristen memberikan suasana ucapan syukur kepada Tuhan atas anugerah yang diberikan melalui karya penebusannya. Pendidikan Kristen menjadi penting ketika menjadi dasar seorang beriman kepada Kristus. Dengan demikian pendidikan agama Kristen merupakan pendidikan yang berdasarkan pada Alkitab berpusat pada Kristus dan dipimpin oleh kuasa roh Kudus yang membimbing umatnya pada tingkat pertumbuhan pengenalan akan Allah melalui Kristus dalam segenap aspek kehidupan mereka.

Pendidikan agama Kristen adalah usaha yang dilakukan oleh seseorang dalam mendewasakan diri beriman menuntun orang bertumbuh dewasa dalam iman dan dituntun oleh Roh Kudus. Pendidikan agama Kristen menolong seseorang sehingga ia menjadi garam dan terang dunia. Pendidikan Kristen secara sadar dan berkesinambungan mengembangkan karakter Kristus untuk memperlengkapi peserta didik sehingga mampu menghayati dan menerapkan hidup kasih yang dinyatakan dalam kehidupan sehari-hari.

Pendidikan Agama Kristen (PAK) bukan sekadar menyampaikan pesan moral apalagi hanya sekadar mengetahui tata cara hubungan antara manusia dengan Tuhan. Pendidikan Kristen harus mampu menyajikan isi kurikulum yang transformatif dan terinternalisasi dalam diri peserta didik. Artinya, isi kurikulum PAK dapat mengubah serta membarui cara pandang dan sikap peserta didik serta mengarahkan peserta didik untuk memahami panggilan Tuhan untuk menjadi berkat bagi sesama dan dunia.

Inti dari Pendidikan Agama Kristen ialah supaya setiap peserta didkik menyadari kasih Allah sebagaimana dinyatakan dalam Yesus Kristus dan menanggapi kasih tersebut melalui iman sehingga mengalami pertumbuhan. Bertumbuh yang dimaksud adalah bertumbuh sebagai anak Allah, hidup sesuai dengan kehendak Allah dan bersekutu dengan sesama.

\section{Hakikat pendidikan agama Kristen.}

Hakikat pendidikan agama Kristen sebenarnya berhubungan dengan aspek pengajaran pengalaman keagamaan. Homrighousen mengatakan bahwa aspek pengajaran dan pendidikan hendaknya membangun kepercayaan Kristen dalam diri para murid dengan jalan menyampaikan pengetahuan. Sedangkan aspek 
PELAKSANAAN PEMBELAJARAN KOOPERATIF TIPE

TWO STAY TWO STRAY UNTUK MENINGKATKAN

HASIL BELAJAR PENDIDIKAN AGAMA KRISTEN

KELAS IV SDN BARATAJAYA SURABAYA

pengalaman keagamaan menekankan perhatian yang dipusatkan pada perkembangan pribadi murid.

Pengajaran iman Kristen merupakan usaha membangun dan menumbuhkan kepercayaan Kristen dalam setiap pribadi untuk menyampaikan pengalaman yang diterima sebagai pengalaman rohani. Pengalaman ini bisa disaksikan kepada sesamanya sebagai bagian dari pada pendidikan Kristen.

Hakikat pendidikan agama Kristen juga harus dipahami dalam kedudukannya sebagai pendidikan dan pengajaran agama Kristen. Samuel Sijabat menyatakan bahwa cara kerja dan misi Kristen harus berakar pada iman Kristen yang didasarkan oleh Alkitab dan tradisi gereja. Dalam mengembangkan tugas pendidikan agama Kristen harus berakar dan berdasar pada kehidupan pribadi Kristus yang digerakkan oleh pribadi Roh Kudus. Pendidikan Kristen harus menjadi guru yang mengarahkan umatnya kepada Kristus sebagai teladan.

\section{Pembelajaran Kooperatif}

Secara etimologi, kooperatif berasal dari bahasa English, "cooperate" yang artinya bekerja bersama. Sedangkan secara terminologi, kooperatif merujuk pada kegiatan mengerjakan sesuatu secara bersama-sama dengan saling membantu satu sama lainnya sebagai suatu kelompok atau satu tim (Erman Suherman).

Pembelajaran kooperatif merupakan istilah yang secara umum untuk menjelaskan sekumpulan strategi pengajaran yang dirancang untuk mendidik kerja sama kelompok dan interaksi antar siswa. Tujuan pembelajaran kooperatif paling tidak meliputi tiga tujuan pembelajaran, yaitu hasil belajar akademik, penerimaan terhadap keragaman, dan pengembangan keterampilan sosial. (Erman Suherman).

Munculnya model pembelajaran kooperatif dapat dilacak pada masa
Yunani. Ia tidak berevolusi dari sebuah teori individual atau dari sebuah pendekatan tunggal tentang belajar. Model pembelajaran ini selanjutnya berkembang awal abad ke-20 melalui hasil karya psikolog pendidikan dan para teoretisi pedagogis, maupun teori-teori pemrosesan informasi yang terkait dengan belajar dan teoretisi-teoretisi kognitif dan perkembangan seperti Piaget dan Vygotsky.

Temuan yang dikembangkan oleh Vygotsky (1978, 1986) yang menekankan pada interaksi sosial sebagai sebuah mekanisme untuk mendukung perkembangan kognitif (Eggen, Paul : 2010).

Selain itu, metode ini juga didukung oleh teori belajar information processing dan cognitive theory of learning (Gunter, Mary A : 2007). Dalam pelaksanaannya metode ini membantu siswa untuk lebih mudah memproses informasi yang diperoleh, karena proses encoding akan didukung dengan interaksi yang terjadi dalam pembelajaran kooperatif. Pembelajaran dengan metode pembelajaran kooperatif dilandasakan pada teori Cognitive karena menurut teori ini interaksi bisa mendukung pembelajaran.

John Dewey adalah tokoh yang pertama kali mencetuskan ide mengenai cooperative learning pada tahun 1916 dalam bukunya yang berjudul Democracy and Education. Kemudian pada kurun waktu 1954-1960, Herbert Thelen mengembangkan prosedur-prosedur yang lebih teliti untuk membantu siswa bekerja dalam kelompok. Eggen dan Kauchack menyatakan bahwa pembelajaran kooperatif merupakan sebuah kelompok strategi pengajaran yang melibatkan siswa bekerja secara berkolaborasi untuk mencapai tujuan bersama (Gunter, Mary A : 2007).

Model cooperative learning yang dipopulerkan sekitar tahun 1950-an merupakan salah satu solusi jalan keluar yang digunakan di Amerika Serikat, terutama tahun 1954 dimana pada masa itu 
terjadi kontak fisik antar ras kulit putih, kulit hitam dan hispanik yang juga terjadi di Spanyol dan Portugis. Pada masa itu, mulai dipopulerkan konsep pembelajaran yang berasaskan kerja sama antar rasial untuk menciptakan kondisi pembelajaran yang saling menguntungkan antara ras dan suku bangsa yang berbeda.

Perkembangan model pembelajaran kooperatif mulai awal kemunculannya sampai sekarang telah melahirkan pemaknaan yang beragam dari para ahli. Beberapa pendapat yang menjelaskan pengertian pembelajaran kooperatif diantaranya adalah Slavin, yang menyatakan bahwa pembelajaran kooperatif adalah suatu model pembelajaran dimana sistem belajar dan bekerja dibuat dalam kelompok-kelompok kecil yang berjumlah 4-6 orang secara kolaboratif sehingga dapat merangsang siswa lebih bergairah dalam belajar. (Trianto). Jumlah anggota kelompok sebanyak 4-6 orang yang dimaksudkan hanya sebatas gambaran, dan dapat disesuaikan dengan jumlah dan heterogenitas siswa dalam satu kelas. Johnson, mengartikan cooperative learning adalah mengelompokkan siswa ke dalam kelompok kecil agar siswa dapat bekerja sama dengan kemampuan maksimal yang mereka miliki dan mempelajari satu sama lain dalam kelompok tersebut (Isjoni). Sementara Anita Lie menyebut pembelajaran kooperatif sebagai pembelajaran gotong royong, yaitu sistem pembelajaran yang memberi kesempatan pada siswa untuk bekerjasama dengan siswa lain dalam tugas-tugas yang terstruktur (Anita Lie).

Walaupun terkesan berbeda, namun setidaknya ada kesamaan dari beberapa definisi yang dikemukakan para ahli, yakni esensi pembelajaran kooperatif terletak pada pembentukan kelompok kecil. Kelompok ini diatur sedemikian rupa agar siswa bisa saling bekerja sama, berinteraksi dan bertukar pikiran dalam proses belajar. Melalui penge- lolaan kelas yang demikian, siswa didorong untuk berinteraksi mengeluarkan kemampuan yang mereka miliki dalam menyelesaikan tugas-tugas yang diberikan. Dalam pembelajaran kooperatif, pembelajaran dikatakan belum selesai jika salah satu teman dalam kelompok belum mengua-sai materi pelajaran.

Dari uraian di atas sekilas telah memberi gambaran tentang keberadaan model pembelajaran kooperatif sebagai salah satu cara mengelola kelas. Sebagai satu diantara model pembelajaran lain, pembelajaran kooperatif tentu memiliki karakteristik tersendiri. Karakteristik inilah yang membedakannya dengan model pembelajaran lain. Karakteristik pembelajaran kooperatif adalah sebagai berikut: Pertama, siswa bekerja dalam kelompok kooperatif untuk menguasai materi akademis. Kedua, anggota-ang-gota dalam kelompok diatur terdiri dari siswa yang berkemampuan rendah, sedang, dan tinggi. Ketiga, jika memungkinkan, masing-masing anggota kelompok kooperatif berbeda suku, budaya, dan jenis kelamin. Keempat, sistem penghargaan yang lebih berorientasi kepada kelompok, bukan individu $(\mathrm{H}$. Chotimah dan Y. Dwitasari : 2009).

Sebelum menerapkan pembelajaran kooperatif, penting bagi pendidik untuk memahami prinsip-prinsip pembelajaran ini. Pendidik harus memastikan bahwa prinsip ini telah terinternalisasi dalam diri siswa, agar hasil yang didapat bisa maksimal. Ada empat prinsip pembelajaran kooperatif, meliputi: Pertama, prinsip Ketergantungan Positif (Positive Interdependence) Agar terciptanya kelompok kerja yang efektif, masing masing anggota kelompok perlu melakukan pembagian tugas. Tugas tersebut tentu disesuaikan dengan kemampuan setiap anggota kelompok. Inilah hakikat ketergantungan positif, artinya setiap anggota kelompok bertanggung jawab atas keberhasilan dalam menyelesaikan tugas kelompok dan semua ini memer- 
PELAKSANAAN PEMBELAJARAN KOOPERATIF TIPE

TWO STAY TWO STRAY UNTUK MENINGKATKAN

HASIL BELAJAR PENDIDIKAN AGAMA KRISTEN

KELAS IV SDN BARATAJAYA SURABAYA

lukan kerjasama yang baik dari masingmasing anggota kelompok (Wina Sanjaya : 2006 ).

Kedua, tanggung Jawab Perseorangan (Individual Accountability). Prinsip ini merupakan konsekuensi dari prinsip yang pertama. Oleh karena keberhasilan kelompok tergantung pada setiap anggotanya, maka setiap anggota kelompok harus memiliki tanggung jawab sesuai dengan tugasnya. Setiap anggota harus memberikan yang terbaik untuk ke-berhasilan kelompoknya. Untuk itu guru perlu memberikan penilaian terhadap individu dan juga kelompok.

Ketiga, interaksi Tatap Muka (Face to Face Promotion Interaction). Pembelajaran kooperatif memberi ruang dan kesempatan yang luas kepada setiap anggota kelompok untuk bertatap muka saling memberikan informasi dan saling membelajarkan. Interaksi tatap muka akan memberikan pengalaman yang berharga kepada setiap anggota kelompok untuk bekerjasama, menghargai setiap perbedaan, memanfaatkan kelebihan masing-masing anggota, dan mengisi kekurangan masing-masing anggota kelompok.

Kempat, partisipasi dan Komunikasi (Participation and Communication). Pembelajaran kooperatif melatih siswa untuk mampu berpartisipasi aktif dan berkomunikasi. Kemampuan ini sangat penting sebagai bekal mereka dalam kehidupan di masyarakat kelak. Untuk dapat melakukan partisipasi dan komunikasi, siswa perlu dibekali dengan kemampuan-kemampuan berkomunikasi.

Keterampilan berkomunikasi memang memerlukan waktu. Oleh sebab itu, guru perlu terus melatih dan melatih, sampai pada akhirnya setiap siswa memiliki kemampuan untuk komunikator yang baik.
Pembelajaran Kooperatif Teknik Two Stay Two Stray (Dua Tinggal Dua Tamu)

Salah satu teknik model pembelajaran kooperatif adalah Teknik Two Stay Two Stray (Dua tinggal - dua tamu). Teknik belajar mengajar ini dikembangkan oleh Spencer Kagan pada tahun 1992 dan biasa digunakan bersama dengan Teknik Kepala Bernomor (Numbered Heads together). Teknik ini bisa digunakan dalam semua mata pelajaran dan untuk semua tingkat usia anak didik. Struktur Two Stay Two Stray memberi kesempatan kepada kelompok untuk membagikan hasil dan informasi dengan kelompok lainnya. Hal ini dilakukan dengan cara saling mengunjungi atau bertamu antar kelompok untuk berbagi informasi (Lie. 2010 : 61 - 62).

\section{METODE PENELITIAN Rancangan Penelitian}

Rancangan dalam penelitian ini adalah penelitian tindakan kelas. Penelitian tindakan kelas merupakan suatu pencermatan terhadap kegiatan belajar berupa sebuah tindakan, yang sengaja dimunculkan dan terjadi dalam sebuah kelas secara bersama. Tindakan tersebut diberikan oleh guru atau dengan arahan guru yang dilakukan oleh siswa (Arikunto, dkk : 2010 )

\section{a. Perencanaan}

Pada tahap perencanaan meliputi

beberapa bagian sebagai berikut: pertama, menelaah materi pembelajaran serta menelaah indikator bersama tim kolaborasi. Kedua, menyusun Rencara Pelaksanaan Pembelajaran sesuai indikator yang telah ditetapkan dengan model pembelajaran kooperatif teknik Two Stay-Two Stray Ketiga, menyiapkan media pembelajaran. Siklus I yaitu berupa gambar Ayub sebelum dicobai Iblis dan setelah Ayub dicobai Iblis. Siklus II yaitu berupa daftar jumlah anak-anak dan harta kepunyaan Ayub sebelum 
dan sesudah mengalami penderitaan: anak laki-laki, anak perempuan, kambing domba, unta, lembu, kedelai. Keempat, menyiapkan alat evaluasi berupa tes tertulis dan lembar kerja siswa. Kelima, menyiapkan lembar observasi untuk mengamati keteram-pilan guru dan aktivitas siswa.

b. Pelaksanaan Tindakan

Pelaksanaan tindakan yaitu implementasi atau penerapan isi rancangan di dalam kegiatan pembelajaran, yaitu mengenakan tindakan di kelas (Arikunto. 2006:99). Dalam pelaksanaan penelitian ini direncanakan dalam dua siklus. Sikluspertama yaitu materi: Mengapa Bergantung kepada Allah? Sub tema: Pendalaman Kisah Ayub dan siklus ke dua dengan materi Mengapa Bergantung kepada Allah? Sub tema: Alasan Hidup bergantung kepada Allah.

c. Observasi

Observasi adalah mengamati dengan suatu tujuan, dengan menggunakan berbagai tekhnik untuk merekam atau memberi kodepada apa yang diamati (Endang purwanti, dkk). Sedangkan menurut Arikunto (2006:156) Observasi meliputi kegiatan pemusatan perhatian terhadap sesuatu objek dengan menggunakan seluruh alat indra. Kegiatan observasi dilaksanakan secara kolaboratif dengan guru pengamat untuk mengamati keterampilan guru dan aktivitas siswa dalam pembelajaran Pendidikan Agama Kristen dengan menggunakan model pembelajaran kooperatif teknik Two stay -Two Stray.

d. Refleksi

Pada tahap refleksi, menemukan kem-bali hal-hal apa saja yang telah terjadi (Arikunto. 2006:99). Setelah mengka-ji proses pembelajaran yaitu keteram-pilan guru dan siswa serta hasil belajar Pendidikan Agama Kristen, apakah pembelajaran terse- but sudah efektif, dengan melihat ketercapaian indikator kinerja pada siklus pertama serta mengkaji kekurangan dengan membuat daftar permasalahan yang muncul dalam pelaksanaan siklus pertama. Kemudian bersama tim kolaborasi mem-buat perencanaan tindak lanjut untuk siklus berikutnya.

\section{A. Perencanaan Tahap Penelitian Perencanaan Dalam II Siklus \\ a. Siklus I \\ 1. Perencanaan}

a). Menyusun RPP dengan materi Mengapa Bergantung ke-pada Allah?

b). Menyiapkan sumber belajar dan media pembelajaran berupa gambar Ayub sebelum dicobai Iblis dan setelah Ayub dicobai Iblis.

c). Menyiapkan alat evaluasi berupa tes tertulis dan lembar kerjasiswa.

d). Menyiapkan lembar observasi dan catatan lapangan untuk mengamati keterampilan guru dan aktivitas siswa.

\section{Pelaksanaan Tindakan}

a). Guru melakukan apersepsi dengan melakukan tanya jawab tentang kegiatan-kegiatan yang terkait dengan kesalehan hidup Ayub.

b). Guru menginformasikan tujuan pembelajaran.

c). Guru membentuk siswa dalam beberapa kelompok, yang terdiri dari4 orang.

d). Setiap siswa diberi nomor dada agar mudah dalam melakukan diskusi Two stayTwo stray.

e). Guru mempresentasikan tentang bagaimana pelaksanaan pembelajaran menggunakan pembelajaran kooperatif tek- 
nik Twostay-Two Stray (dua tinggal-dua tamu).

f). Guru menginformasikan materi kepada siswa.

g). Masing-masing kelompok diberi Lembar kerja (LKS).

h). Secara kelompok siswa mendiskusikan tentang permasalahan yang terdapat dalam LKS

i). Guru membimbing diskusi.

j). Setelah diskusi kelompok selesai, siswa yang bernomor dada 1 dan2 tetap dalam kelompok dan bertugas membagikan informasi pada kelompok tamu.

k). Siswa yang bernomor dada 3 dan 4 bertamu ke kelompok lain dan bertugas menggali informasi pada tuan rumah.

1). Tamu mohon diri dan kembali ke kelompok mereka sendiri dan melaporkan temuan mereka dari kelompok lain.

m). Kelompok mencocokkan dan membahas hasil-hasil kerja mereka.

n). Siswa mempresentasikan hasil diskusi dan guru membahas hasil kerja kelompok

o). Guru memberi evaluasi.

p). Guru menganalisa hasil evaluasi.

\section{Observasi}

Pada tahap observasi melakukan hal sebagai berikut: Melakukan pengamatan aktivitas Guru kelas IV SDN Baratajaya Surabaya dalam mengajar dengan teknik Two Stay-Two Sray. Melakukan pengamatan aktivitas siswa kelas IV SDN Baratajaya dalam pembelajaran Pendidikan Agama Kristen dengan menerapkan teknik Two Stay-Two Sray

\section{Refleksi}

Dalam hal ini peneliti dan guru mitra mengkaji prosespembelajaran yang
KELAS IV SDN BARATAJAYA SURABAYA telah dilaksanakan pada siklus I. Membuat daftarpermasalahan yang muncul pada saat pembelajaran serta mengevaluasi proses dan hasil untuk digunakan sebagai perbaikan perencanaan siklus II.

\section{b. Siklus II}

\section{Perencanaan}

a) Menyusun RPP dengan materi Mengapa Bergantung kepada Allah? Sub tema: Alasan Hidup bergantung kepada Allah.

b) Menyiapkan daftar jumlah anakanak dan harta kepunyaan Ayub sebelum dan sesudah mengalami penderitaan: anak laki-laki, anak perempuan, kambing domba, unta, lembu, kedelai.

c) Menyiapkan alat evaluasi berupa tes tertulis dan lembar kerjasiswa.

d) Menyiapkan lembar observasi dan catatan lapangan untuk mengamati keterampilan guru dan aktivitas siswa.

\section{Pelaksanaan Tindakan}

Tahapan dalam pelaksanaan tindakan adalah sebagai berikut:

a). Guru melakukan apersepsi dengan menggali pengetahuan awal siswa melalui pertanyaan.

b). Guru menginformasikan tujuan pembelajaran.

c). Guru mengingatkan kembali tentang bagaimana pelaksanaan pembelajaran menggunakan model kooperatif Two stay-Two Stray.

d). Guru menginformasikan materi kepada siswa.

e). Guru memberi perintah pada siswa untuk duduk sesuai kelompok yang telah dibentuk pada pertemuan sebelumnya.

f). Masing-masing kelompok diberi Lembar kerja Siswa (LKS). 
g). Secara kelompok siswa mendiskusikan tentang permasalahan yang terdapat dalam LKS

h). Guru membimbing dalam diskusi.

i). Setelah diskusi kelompok selesai, siswa yang bernomor dada 1 dan 2 tetap dalam kelompok dan bertugas membagikan informasi pada kelompok tamu.

j). Siswa yang bernomor dada 3 dan 4 bertamu ke kelompok lain dan bertugas menggali informasi pada tuan rumah berupa menanyakan semua informasi terkait materi.

k). Kelompok tamu diperbolehkan bertamu pada kelompok yang belum mereka kunjungi.

1). Kelompok tamu mohon diri dan kembali ke kelompok mereka sendiri dan melaporkan temuan mereka dari kelompok lain.

m). Kelompok mencocokkan dan membahas hasil-hasil kerja mereka.

n). Siswa dan guru membahas hasil kerja kelompok.

o). Guru memberi evaluasi.

p). Guru menganalisa hasil evaluasi.

\section{Observasi}

Pada tahap ini melakukan hal berikut:

a) Melakukan pengamatan aktivitas Guru kelas IV SDN Baratajaya dalam mengajar dengan teknik Two Stay-Two Sray.

b) Melakukan pengamatan aktivitas siswa kelas IV SDN Baratajaya dalam pembelajaran Pendidikan Agama Kristen dengan menerapkan teknik Two Stay-Two Sray

\section{Refleksi.}

Dalam hal ini peneliti dan guru mitra mengkaji proses pembelajaranyang telah dilaksanakan pada siklus II. Membuat daftar permasalahan yang muncul pada saat pembelajaran serta mengevaluasi proses dan hasil untuk digunakan sebagai perbaikan perencanaan siklus selanjutnya.

\section{B. Subjek Penelitian}

Subjek penelitian ini adalah Guru kelas IV dan 9 Siswa kelas IV yang terdiri dari 2 siswa laki-laki dan 7 siswa perempuan.

\section{Tempat Penelitian}

Penelitian ini dilaksanakan di SDN Baratajaya Surabaya. Sekolah ini terletak di jalan Baratajaya VIII no 43 kelurahan Baratajaya Kecamatan Gubeng kota Surabaya. Sekolah ini berdiri sejak tahun 1970 dan memiliki luas tanah 2.197 meter persegi. Secara umum SDN Baratajaya layak di teliti mulai jenjang tingkat rendah sampai tinggi karena sudah berusia 49 tahun. Kemajuan pendidikan terletak pada pundak para pendidik jaman kini dalam memajukan kualitas pendidikan kedepan.

\section{Variabel penelitian}

Variabel dalam penelitian ini adalah sebagai berikut: Keterampilan guru dalam pembelajaran Pendidikan Agama Kristen dengan model pembelajaran kooperatif teknik Two stay-Two stry. Aktifitas siswa dalam pembelajaran Pendidikan Agama Kristen dengan model pembelajaran kooperatif teknik Two stay-Two stray. Hasil belajar Pendidikan Agama Kristen dengan model pem-belajaran Kooperatif teknik Twostay-Two stray.

\section{E. Data dan Cara Pengumpulan Data}

\section{Sumber data}

\section{a). Siswa.}

Sumber data siswa diperoleh dari hasil observasi yang diperoleh secara sistematik selama pelaksanaan siklus pertama sampai siklus kedua, hasil evaluasi, dan catatan lapangan. 
b). Guru

Sumber data guru berasal dari hasil observasi keterampilan guru dan catatan lapangan dalam pembelajaran Pendidikan Agama Kristen dengan menerapkan model pembelajaran kooperatif teknik Two Stay-Two Stray.

c). Data Dokumen

Sumber data dokumen berupa data awal nilai hasil evaluasi pembelajaran Pendidikan Agama Kristen sebelum dilakukan tindakan.

\section{Jenis Data}

a). Data Kuantitatif

Data Kuantitatif diwujudkan dengan hasil belajar berupa nilai yang diperoleh siswa dalam pembelajaran Pendidikan Agama Kristen.

b). Data Kualitatif

Data kualitatif diperoleh dari hasil observasi dengan menggunakan lembar pengamatan keterampilan guru, aktivitas siswa dan catatan lapangan dalam pembelajaran Pendidikan Agama Kristen dengan model pembelajaran kooperatif teknik two stay-two stray.

\section{Teknik Pengumpulan Data}

a) Metode Observasi

Menurut Endang Purwanti, Observasi adalah mengamati dengan suatu tujuan dengan menggunakan berbagai teknik untuk merekam atau memberi kode pada apa yang diamati sedangkan menurut Arikunto (2006 : 156) Observasi meliputi kegiatan pemusatan perhatian terhadap sesuatu objek dengan menggunakan seluruh alat indra. Observasi dalam penelitian ini digunakan untuk menggambarkan keterampilan guru dan aktivitas siswa dalam pembelajaran Pendidikan Agama Kristen dengan menggunakan model pembelajaran kooperatif teknik TwoStay-Two Stray. b). Metode Tes

Tes adalah serentetan pertanyaan atau latihan serta alat lain yang digunakan untuk mengukur keterampilan, pengetahuan intelegensi, kemampuan atau bakat yang dimiliki oleh individu atau kelompok (Arikunto. 2006 : 150). Metode tes dalam penelitian ini digunakan untuk melihat kemampuan siswa dalam pembelajaran Pendidikan Agama Kristen.

\section{c). Metode Dokumentasi}

Dokumentasi merupakan catatan peristiwa yang sudah berlalu yang berbentuk tulisan, gambar, atau karya-karya monumental dari seseorang (Sugiono, 2007 : 329) Metode dokumentasi dalam penelitian ini adalah untuk melihat gambaran tentang kegiatan guru dan siswa dalam pembelajaran.

d). Catatan lapangan.

Lapangan Catatan lapangan berisi tentang permasalahan-permasalahan yang terjadi pada saat pembelajaran Pendidikan Agama Kristen berlangsung. Catatan lapangan tersebut bertujuan untuk membantu peneliti apabila menemui kesulitan dan sebagai solusi untuk memecahkan permasalahan agar guru dapat melakukan refleksi.

F. Teknik Analisis Data

Teknik analisis data yang digunakan adalah :

1. Kuantitatif

Data kuantitatif berupa hasil belajar kognitif, dianalisis dengan menggunakan teknik analisis deskriptif dengan menentukan mean atau rerata. Adapun rumus menentukan rerata adalah sebagai berikut:

$$
\mathrm{X}=\sum \mathrm{X}: \sum \mathrm{N}
$$


Keterangan :

$\mathrm{X}$ : nilai rata-rata

$\sum X \quad$ : jumlah semua nilai siswa

$\sum \mathrm{N}$ : Jumlah siswa

(Aqib, Zaenal dkk. 2009: 41)

Untuk menghitung presentase ketuntasan belajar digunakan rumus sebagai berikut :

$\mathrm{P}=\sum \mathrm{X}$ siswa yang tuntas $\mathrm{X} 100 \%$ ¿siswa

Hasil analisis juga dijadikan sebagai bahan refleksi dalam memperbaiki rancangan pembelajaran selanjutnya (Aqib, Zaenal dkk.2009: 41)

\section{Tabel 1}

Klasifikasi kategori tingkatan presentase untuk ketuntasan belajar

\begin{tabular}{|c|c|c|}
\hline $\begin{array}{c}\text { Pencapai } \\
\text { Tujuan } \\
\text { Pembelajaran }\end{array}$ & Kategori & $\begin{array}{c}\text { Tingkat } \\
\text { Keberhasilan } \\
\text { Pembelajaran }\end{array}$ \\
\hline $85-100 \%$ & Sangat Baik & Tuntas \\
\hline $65-84 \%$ & Baik & Tuntas \\
\hline $55-64 \%$ & Cukup & Tidak Tuntas \\
\hline $0-54 \%$ & Kurang & Tidak Tuntas \\
\hline
\end{tabular}

2. Kualitatif

Data kualitatif diperoleh dari menganalisis lembar observasi yang telah diisi pada saat pembelajaran Pendidikan Agama Kristen dengan model kooperatif teknik Two Stay - Two stray. Untuk lembar pengamatan keterampilan guru dan aktivitas siswa menggunakan skala penilaian. Skala adalah alat untuk mengukur nilai, sikap, minat dan perhatian dan lainlain. Skala nilai bisa juga menggunakan kategori sangat baik, baik, cukup dan kurang atau dengan angka $4,3,2$, 1. Skala penilaian dapat menghasilkan data interval dalam bentuk skor nilai melalui jumlah skor yang diperoleh dari instrument tersebut (Sudjana, Nana, 2009 : 7).

Tabel 2

Klasifikasi kategori nilai untuk lembar pengamatan keterampilan guru dan aktifitas siswa.

\begin{tabular}{|c|c|}
\hline Skala Penilaian & Kategori \\
\hline $3,1-4$ & Sangat Baik \\
\hline $2,1-3$ & Baik \\
\hline
\end{tabular}

\begin{tabular}{|l|l|}
\hline $1,1-2$ & Cukup \\
\hline $0,1-1$ & Kurang \\
\hline
\end{tabular}

\section{G. Indikator Keberhasilan}

Pembelajaran dengan model pembelajaran kooperatif teknik Two Stay-Two Stray dapat meningkatkan kualitas pembelajaran Pendidikan Agama Kristen pada siswa kelas IV SDN Baratajaya dengan kriteria sekurang-kurangnya baik.

Aktivitas siswa dalam pembelajaran Pendidikan Agama Kristen dengan model pembelajaran kooperatif teknik Two Stay-Two Stray mengalami peningkatan dengan kriteria sekurang-kurangnya baik. $75 \%$ siswa kelas IV SDN Baratajaya mengalami ketuntasan belajar individual sebesar $\geq 65$ dalam pembelajaran Pendidikan Agama Kristen.

\section{HASIL PENELITIAN DAN PEMBAHASAN}

Model Pembelajaran Kooperatif teknik Two Stay-Two Stray pada bab ini akan dibuktikan meningkatkan keterampilan guru, aktifitas siswa dalam pembelajaran, dan meningkatkan hasil belajar. Salah satunya melalui kualitas pembelajaran Pendi-dikan Agama Kristen yang mening-kat. Penelitian ini melaksanakan dua siklus, karena pada siklus kedua indikator keberhasilan telah tercapai. Berikut ini dipaparkan hasil penelitian yang terdiri atas keterampilan guru, aktifitas siswa dalam proses pembelajaran, dan hasil belajar Pendidikan Agama Kristen dengan menerapkan model pembelajaran kooperatif teknik twostay-two stray pada siswa kelas IV SDN Baratajaya Surabaya.

I. Deskripsi Data Pelaksanaan Tindakan siklus I

a) Perencanaan.

Hal-hal yang dilakukan pada perencanaan siklus I adalah sebagai berikut :

(1) Menyusun Rencana Pelaksanaan pembelajaran (RPP) mata 
pelajaran Pendidikan Agama Kristen dengan materi Mengapa Bergantung kepada Allah?

(2) Menyiapkan sumber belajar dan media pembelajaran berupa gambar Ayub sebelum dicobai Iblis dan setelah Ayub dicobai Iblis.

(3) Menyiapkan alat evaluasi berupa tes tertulis dan lembar kerja siswa.

(4) Menyiapkan lembar observasi keterampilan guru dan aktivitas siswa dalam pembelajaran serta catatan lapangan yang akan digunakan dalam penelitian.

b) PelaksanaanTindakan

Pelaksanaan pembelajaran siklus I dilaksanakan pada hari Selasa, 12 Februari 2019 dengan lama waktu $4 \times$ 35 menit yang dimulai dari pukul 07.00 sampai dengan 09.30 WIB. Pembelajaran membahas pelajaran mengapa hidup bergantung Allah? sub tema: Pendalaman kisah Ayub sub dengan uraian kegiatan sebagai berikut : kegiatan pada pertemuan siklus pertama ini adalah meliputi pra pembelajaran, kegiatan awal, kegiatan inti, dan kegiatan akhir.

c) Deskripsi observasi proses pembelajaran

(1) Observasi Keterampilan Guru Berdasarkan lembar pengamatan keterampilan guru ada empat komponen yang diamati atau sub indikator yaitu:

a) Pada saat pra kegiatan pembelajaran, meliputi: salam, doa, presensi, menyiapkan media pembelajaran, dan kondisi kelas.

b) Pada saat kegiatan awal, meliputi: apersepsi dan menginformasikan tujuan pembelajaran dengan baik.

c) Pada saat kegiatan inti, meliputi: memotivasi siswa, menggali pengetahuan siswa
KELAS IV SDN BARATAJAYA SURABAYA

melalui pertanyan, menyampaikan materi, menggunakan media pembelajaran dengan baik, membimbing siswa dalam pembentukan kelompok, membimbing diskusi dalam kelompok, membimbing pembagian tugas untuk bertamu dan menerima tamu, membimbing siswa dalam menyampaikan informasi dan hasil kerja kepada kelompok tamu, membimbing siswa dalam mencocokkan hasil temuan mereka dari kelompok lain, membimbing siswa dalam mempresentasikan hasil diskusi kelompok, membimbing membahas hasil kerja kelompok, memberikan penguatan dan penghargaan kepada kelompok, menguasai materi pelajaran, pengelolaan waktu.

d) Pada saat kegiatan akhir, meliputi: membimbing siswa dalam menyimpulkan materi, memberi kesempatan pada siswa untuk menanyakan halhal yang belum dimengerti, memberikan evaluasi.

Tabel 3

Data Ketrampilan Guru Siklus

I

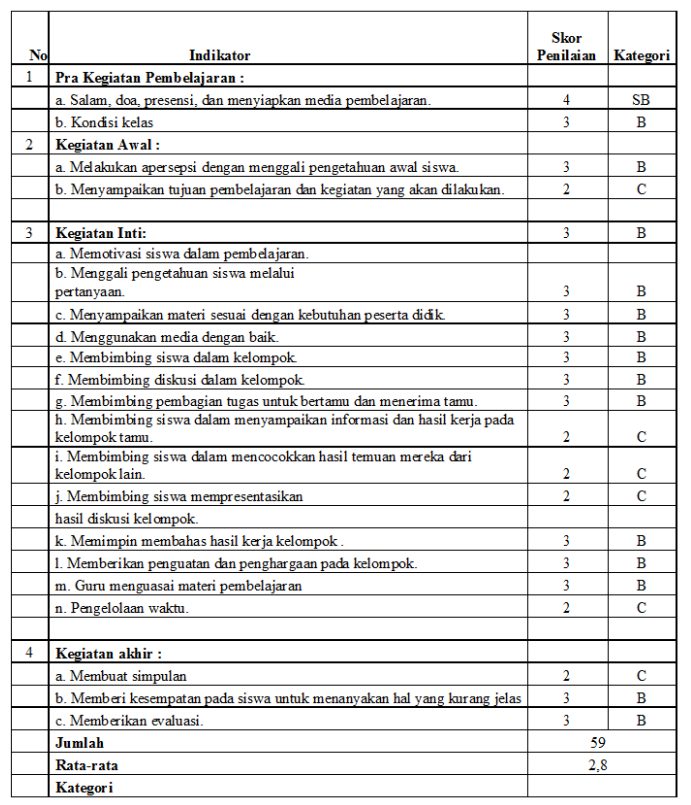


Pada tabel 3 menunjukkan keterampilan guru dengan perolehan skor 59, rata-rata 2,8 dan termasuk dalam kategori baik. Proses pembelajaran sudah berlangsung dengan baik sesuai dengan rencana pelaksanaan pembelajaran (RPP). Data hasil pengamatan keterampilan $\mathrm{Gu}$ ru secara lengkap dapat dilihat dalam lampiran 7. Disini guru masih belum terbiasa dalam melaksanakan pem-belajaran dengan menggunakan mo-del kooperatif teknik two stay-two stray dalam pembelajaran Pendidikan Agama Kristen. Meskipun begitu kegiatan pembelajaran dapat berjalan dengan baik dan lancar. Guru membuka dan menyiapkan media pembelajaran dengan sangat baik. Situasi dan kondisi pembelajaran dilakukan dengan baik.

Guru memberikan apersepsi dengan baik dan menyampaikan tujuan pembelajaran dan kegiatan yang akan dilakukan dengan cukup. Guru memotivasi siswa dengan baik sehingga mayoritas siswa termotivasi dalam pembelajaran. Menggali pengetahuan awal siswa dengan pertanyaanpertanyaan yang berhubungan dengan materi ajar. Guru menyampaikan materi dengan bahasa yang mudah dipahami. Guru menggunakan media pembelajaran dengan baik. Guru membimbing siswa dalam pembentukan kelompok, sehingga anggota kelompok menjadi heterogen. Guru juga sudah memberikan bimbingan kepada kelompok dengan cukup baik, dengan membantu kelompok yang mengalami kesulitan. Membimbing pembagian tugas dengan baik, yaitu dengan cara memberikan nomor dada kepada anggota kelompok sehingga setiap siswa tidak kebingungan dengan tugasnya masing-masing (siswa yang bernomor dada 1 dan 2 bertugas menerima tamu dan siswa yang bernomor dada 3 dan 4 bertugas bertamu ke kelompok lain). Guru membimbing siswa dalam menyampaikan informasi dan hasil kerja kepada kelompok tamu, membimbing siswa dalam mencocokkan temuan dari kelompok lain, dan mempresentasikan hasil kerja kelompok dengan cukup. Selain itu guru juga sudah memberi masukan kepada kelompok yang tidak mau bekerja sama agar mau bekerja sama dengan baik. Guru memotivasi siswa supaya peserta didik mengeluarkan pendapat.

Dalam kegiatan menyimpulkan materi guru sudah mengajak siswa untuk menyimpulkan materi bersamasama. Dalam menilai siswa, guru masih menilai berdasarkan tes akhir yang diperoleh siswa. Guru juga sudah memberi penghargaan dan motivasi pada saat proses pembelajaran berlangsung.

\section{(2) Observasi Aktivitas Siswa}

Pada siklus I, selain mengamati keterampilan guru, guru mitra juga mengamati setiap kejadian, perilaku, perubahan pada siswa. Guru mitra mengamati aktivitas siswa dengan menggunakan lembar observasi aktivitas siswa. Berdasarkan hasil observasi atau pengamatan aktivitas siswa menunjukan Pembelajaran Pendidikan Agama Kristen dengan menggunakan model kooperatif teknik two stay-two stray diperoleh rata-rata skor 3,09 dengan rata-rata $66 \%$ masuk dalam kategori baik. Sebagian siswa sudah mendengarkan penjelasan guru dengan baik akan tetapi masih ada beberapa siswa yang tidak memperhatikan dan sibuk sendiri. Pembelajaran dengan model kooperatif teknik two stay-two stray masih jarang digunakan oleh guru dalam pembelajaran Pendidikan Agama 
PELAKSANAAN PEMBELAJARAN KOOPERATIF TIPE

TWO STAY TWO STRAY UNTUK MENINGKATKAN

HASIL BELAJAR PENDIDIKAN AGAMA KRISTEN

KELAS IV SDN BARATAJAYA SURABAYA

Kristen, sehingga siswa mengalami peningkatan dalam hal mendengarkan penjelasan guru. Hal ini terjadi terutama pada saat guru menjelaskan dengan menggunakan media pembelajaran, anak-anak terlihat antusias dalam mendengarkan penjelasan guru tersebut.

Siswa sudah melakukan diskusi sesuai dengan petunjuk guru, hal ini terlihat dari rata-rata skor yang diperoleh dalam indikator ini adalah 3,55 masuk dalam kategori sangat baik. Siswa dapat bertanggung jawab atas tugas mereka masing-masing, hal tersebut terlihat pada saat menerima tamu, siswa terlihat menyampaikan informasi dengan baik begitu pula sebaliknya, siswa yang bertugas menggali informasi bekerja dengan baik walaupun beberapa siswa tidak mau jika mendapatkan tamu yang tidak mereka sukai. Dalam indikator ini siswa mendapatkan skor rata-rata 3 masuk dalam kriteria baik. Siswa sudah dapat bekerjasama dalam kegiatan kelompok walaupun masih ada beberapa siswa yang mendominasi.

Dalam hal ini siswa mendapatkan skor rata-rata 3,03 masuk dalam kategori sangat baik. Sebagian besar siswa sudah mulai mengemukakan pendapatnya, ikut melaksanakan setiap kegiatan kelompok dengan baik. Siswa sering menanyakan ma-teri yang belum dimengerti, padahal hal tersebut sudah ditanyakan oleh temannya. Hal tersebut sering terjadi apabila guru menjelaskan pada saat siswa sudah masuk dalam kelompok. Akan tetapi hal tersebut menandakan bahwa siswa aktif dalam menanyakan materi yang belum dimengerti. Dalam hal ini siswa mendapatkan rata-rata skor 2,88 dengan kategori baik. Siswa aktif menjawab pertanyaan dari guru dengan perolehan rata rata skor 2,77 masuk dalam kategori baik.
(3) Paparan Hasil Belajar Siswa

Pada akhir pembelajaran guru melakukan ujian tertulis untuk mengetahui peningkatan hasil belajar siswa terhadap pembelajaran sebelumnya yaitu sebelum dilakukan tindakan. Berikut adalah data hasil belajar siswa siklus I :

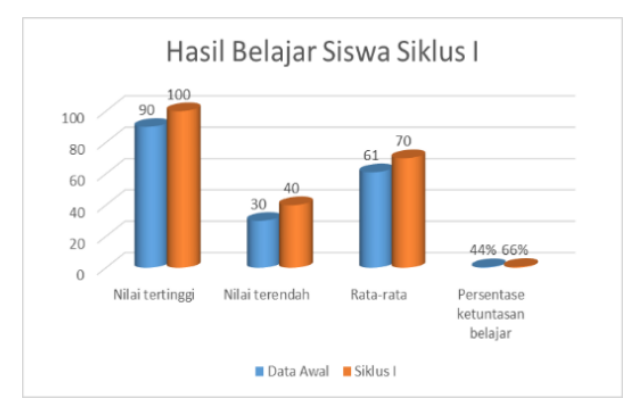

Menurut data tabel di atas, data awal sebelum dilakukan tindakan nilai rata-rata kelas adalah 61 dengan nilai terendah 30 dan nilai tertinggi 90 . Ketuntasan belajar klasikal sebelum dilakukan tindakan adalah sebesar 44\%. Setelah dilakukan tindakan siklus I dengan menggunakan model pembelajaran kooperatif teknik two stay-two stray, terjadi peningkatan hasil belajar siswa dengan rerata kelas 70, nilai tertinggi adalah 100 dan nilai terendah adalah 40. Ketuntasan belajar klasikal sebesar $66 \%$.

Hal ini menunjukkan bahwa $66 \%$ siswa yaitu 6 dari 9 siswa mangalami ketuntasan belajar, dan 33\% siswa yaitu 3 tidak tuntas dari 9 siswa. Akan tetapi ketuntasan belajar Pendidikan Agama Kristen tersebut belum mencapai target yang diinginkan, yang tercantum

dalam indikator keberhasilan yaitu sekurang-kurangnya $75 \%$ dari ketuntasan belajar individual siswa.

c) Refleksi

Secara garis besar kegiatan dalam siklus I ini sudah baik, akan tetapi tingkat keberhasilan belum terlihat secara signifikan. Permasalahan yang 
muncul dalam proses pembelajaran siklus I adalah sebagai berikut,

Siswa kurang mendengarkan penjelasan guru apabila sudah masuk dalam kelompok, beberapa siswa masih mendominasi dalam kegiatan kelompok, beberapa siswa enggan bergabung dengan teman yang tidak disukai, namun guru memberikan pengertian sehingga siswa mau bergabung dengan siapapun, kerja kelompok masih kurang tertib, guru tidak membahas lembar kerja siswa secara detail, hanya secara garis besarnya saja, presentasi kelompok masih belum maksimal karena kelompok lain tidak mau mendengarkan. Dari permasalahan-permasalahan tersebut maka perlu diadakan perbaikan pada siklus selanjutnya.

\section{d) Revisi}

Adapun perbaikan untuk siklus berikutnya adalah sebagai berikut, guru menjelaskan secara detail kegiatan yang akan dilakukan di awal pembelajaran yaitu sebelum siswa masuk dalam kelompoknya masing-masing. Hal tersebut dilakukan agar siswa dapat berkonsentrasi dalam mendengarkan penjelasan guru. Guru memberikan motivasi pada semua siswa bahwa setiap anggota kelompok harus senantiasa berpartisipasi dalam kegia-tan kelompok. Memberikan pengertian kepada beberapa siswa bahwa kerja kelompok dapat dilakukan dengan siapapun. Menertibkan segala kegiatan kelompok dengan cara memantau kegiatan mereka serta mencatat nama-nama siswa yang menjadi biang keladi kegaduhan. Guru membahas lembar kerja siswa secara menyeluruh. Guru meminta setiap kelompok untuk mengoreksi kerja kelompoknya masing-masing pada saat kelompok lain melakukan presentasi.
2. Deskripsi data pelaksanaan siklus II a. Perencanaan

Langkah yang dilakukan pada tahap perencanaan siklus II adalah memperbaiki skenario pembelajaran dengan menggunakan model pembelajaran kooperatif teknik two stay-two stray, sesuaidengan hasil refleksi siklus I. Hal ini dimaksudkan supaya pelaksanaan siklus II dapat berjalan dengan lancar sesuai dengan yang diharapkan sehingga dapat memperbaiki kekurangan pada siklus I.

Hal-hal yang dilakukan pada perencanaan siklus II adalah sebagai berikut, pertama, menyusun Rencana Pelaksanaan pembelajaran (RPP) mata pelajaran Pendidikan Agama Kristen dengan materi Mengapa Bergantung kepada Allah? Sub tema : Alasan Hidup bergantung kepada Allah (Lampiran 12). Kedua, menyiapkan sumber belajar dan alat peraga berupa kartu daftar jumlah anak-anak dan harta kepunyaan Ayub sebelum dan sesudah mengalami penderitaan: anak laki-laki, anak perempuan, Kambing Domba, Unta, Lembu, Kedelai. Ketiga, menyiapkan alat evaluasi berupa tes tertulis dan lembar kerjasiswa. Keempat, menyiapkan lembar observasi dan catatan lapangan untuk mengamati keterampilan guru dan aktivitas siswa.

b. Pelaksanaan Tindakan

Pelaksanaan pembelajaran siklus II dilaksanakan pada hari Selasa, 19 Maret 2019 dengan lama waktu 4 x 35 menit yang dimulai dari pukul 07.00 sampai dengan 09.30 WIB. Pembelajaran membahas materi mengapa bergantung kepada Allah? Sub tema: Alasan Hidup bergantung kepada Allah dengan uraian kegiatan sebagai berikut, kegiatan pada pertemuan siklus dua ini adalah meliputi pra kegiatan pembelajaran, kegiatan awal, kegiatan inti, dan kegiatan akhir. 
c) Observasi

(1) Observasi Keterampilan Guru

Berdasarkan lembar pengamatan keterampilan guru ada empat komponen yang diamati atau sub indikator yaitu:

(a) Pada saat pra kegiatan pembelajaran, meliputi: salam, doa, presensi, menyiapkan media pembelajaran, dan mengkondisikan kelas.

(b)Pada saat kegiatan awal, meliputi: apersepsi, dan menginformasikan tujuan pembelajaran dengan baik.

(c) Pada saat kegiatan inti, meliputi: memotivasi siswa, menggali pengetahuan siswa melalui pertanyaan, menyampaikan materi, menggunakan media pembelajaran dengan baik, membimbing siswa dalam pembentukan kelompok, membimbing diskusi dalam kelompok, membimbing pemba-gian tugas untuk bertamu dan menerima tamu, membimbing siswa dalam menyampaikan informasi dan hasil kerja kepada kelompok tamu, membimbing siswa dalam mencocokkan hasil temuan mereka dari kelompok lain, membimbing siswa dalam mempresentasikan hasil diskusi kelompok, membimbing membahas hasil kerja kelompok, memberikan penguatan dan penghargaan kepada kelompok, menguasai materi pelajaran, pengelolaan waktu.

d. Pada saat kegiatan akhir, meliputi: membimbing siswa dalam menyimpulkan materi, memberi kesempatan pada siswa untuk menanyakan hal-hal yang belum dimengerti, memberikan evaluasi. Dari penjelasan empat komponen di atas digunakan untuk memperoleh data keterampilan guru.

(2) Observasi Aktivitas Siswa

Berdasarkan hasil observasi atau pengamatan aktivitas siswa dalam
KELAS IV SDN BARATAJAYA SURABAYA

pembelajaran Pendidikan Agama Kristen dengan menggunakan model kooperatif teknik two staytwo stray, diperoleh rata-rata skor 3,17 dengan rata-rata presentase $88 \%$ masuk dalam kategori sangat baik.

Melalui pengamatan aktivitas siswa, siklus II ini mengalami peningkatan dibanding dengan siklus I. Hal ini terlihat dari peningkatan skor beberapa indikator. Dari pengamatan tersebut sebagian besar siswa mendengarkan penjelasan dengan sangat baik, beberapa siswa yang pada siklus I masih bermain sendiri dan berbicara dengan teman sebelahnya sudah terkondisikan walaupun belum semua siswa. Ratarata skor yang didapat pada indikator tersebut yaitu sebesar 3,77. Siswa melakukan diskusi sesuai dengan petunjuk guru. Kegiatan diskusi bertamu dan menerima tamu sudah berjalan dengan tertib dan mendapatkan skor 3,44 dan masuk dalam kriteria sangat baik. Tidak ada lagi anak yang menolak bekerja sama dengan teman yang tidak ia sukai. Para siswa sudah mulai terbiasa bergabung dengan semua teman, tanpa memilih milih lagi. Siswa dapat bekerja sama dengan baik. Siswa sudah tidak ragu-ragu lagi dalam mengeluarkan pendapat, semua anggota kelompok berpartisipasi aktif dalam segala kegiatan dalam kelompok dan mendapatkan rata-rata skor 3,11 masuk dalam kategori sangat baik. Siswa antusias dalam mengajukan dan menjawab pertayaan guru. Kedua indikator tersebut masuk dalam kategori sangat baik.

(3) Hasil Belajar Siswa

Pada akhir pembelajaran guru melakukan ujian tertulis untuk mengetahui peningkatan hasil 
belajar siswa terhadap pembelajaran sebelumnya. Berikut adalah data hasil belajar siswa siklus II :

\section{Tabel 4}

Hasil Belajar Siswa Siklus II

\begin{tabular}{|c|l|c|c|}
\hline No & \multicolumn{1}{|c|}{ Hasil belajar } & Data Awal & Siklus I \\
\hline 1 & Nilai tertinggi & 100 & 100 \\
\hline 2 & Nilai terendah & 40 & 50 \\
\hline 3 & Rata-rata & 70 & 70 \\
\hline 4 & $\begin{array}{l}\text { Persentase ketuntasan } \\
\text { belajar }\end{array}$ & $69 \%$ & $80 \%$ \\
\hline
\end{tabular}

Peningkatan hasil belajar pada tiap siklus cukup signifikan, hal ini menunjukkan bahwa pembelajaran yang dilakukan pada tiap siklus berhasil sampai mencapai indikator keberhasilan yang diharapkan. Nilai rata-rata mencapai 70 dan jumlah siswa yang tuntas belajar juga mengalami peningkatan yaitu 8 siswa dari 9 siswa atau $88 \%$. Kriteria tingkat keberhasilan siswa pada siklus II masuk dalam kategori baik. Data tersebut menunjukkan bahwa hasil belajar pada siklus II telah mencapai indikator yang ditentukan yaitu ketuntasan minimal sebesar $75 \%$.

\section{d) Refleksi}

Kegiatan yang dilaksanakan pada siklus II secara keseluruhan sangat baik dan mencapai target yang diinginkan. Guru memahami dan mampu menerapkan model pembelajaran kooperatif teknik two stay-two stray, sehingga aktivitas guru meningkat, aktivitas siswa meningkat, hasil belajar meningkat, dampaknya kualitas pembelajaran Pendidikan Agama Kristen juga meningkat. Akan tetapi ada beberapa hal yang perlu diperhatikan dalam pembelajaran berikutnya, antara lain ketertiban siswa dalam melaksanakan diskusi, pengelolaan kelas juga masih perlu ditingkatkan. e) Revisi

Berdasarkan masukan dari kolaborator, pembelajaran telah berhasil dengan baik. Akan tetapi perbaikan mutu pembelajaran harus tetap dilanjutkan lagi pada pembelajaran berikutnya.Hal yang perlu ditekankan pada pelaksanaan pembelajaran berikutnya adalah membiasakan ketertiban dalam kerja kelompok dan pengelolaan kelas yang lebih baik lagi. Berikut ini hasil keterampilan guru, dan aktivitas siswa dengan menggunakan model pembelajaran kooperatif teknik two stay-two stay pada silus I dan siklus II.

Skor rata-rata keterampilan guru pada siklus I adalah 2,85 dengan persentase $66 \%$ termasuk dalam kategori baik, pada siklus II adalah 3,33 masuk dalam kategori sangat baik dengan persentase $88 \%$. Hal ini menunjukkan bahwa terjadi peningkatan pada keterampilan guru sebesar 0,48 dengan persentase $48 \%$. Sedangkan rata-rata aktivitas siswa pada siklus I adalah 3,09 dengan persentase $66 \%$, pada siklus II menjadi 3,17 dengan persentase $88 \%$ sehingga terjadi peningkatan yang cukup baik yaitu sebesar 0,08 dengan persentase $8 \%$. Hal ini menunjukkan bahwa terjadi peningkatan pada keterampilan guru danaktivitas siwa mempengaruhi peningkatan hasil belajar siswa sehingga kualitas pembelajaran Pen-didikan Agama Kristen meningkat.

Berikut ini hasil belajar siswa yang dimulai dari data awal,siklus I, dan siklus II.

Tabel 5

Hasil belajar data awal, siklus I, dan siklus II.

\begin{tabular}{|c|l|c|c|}
\hline No & \multicolumn{1}{|c|}{ Hasil Capaian } & $\begin{array}{c}\text { Siklus } \\
\text { I }\end{array}$ & $\begin{array}{c}\text { Siklus } \\
\text { II }\end{array}$ \\
\hline 1 & $\begin{array}{l}\text { Rata-rata } \\
\text { Keterampilan Guru }\end{array}$ & 2,85 & 3,33 \\
\hline 2 & $\begin{array}{l}\text { Rata-rata Aktifitas } \\
\text { Siswa }\end{array}$ & 3,09 & 3,17 \\
\hline
\end{tabular}


PELAKSANAAN PEMBELAJARAN KOOPERATIF TIPE

TWO STAY TWO STRAY UNTUK MENINGKATKAN

HASIL BELAJAR PENDIDIKAN AGAMA KRISTEN

Berdasarkan tabel diatas dapat disimpulkan bahwa data awal menunjukkan nilai rata-rata 61 sehingga siswa belum mencapai ketuntasan belajar. Setelah dilaksanakan pembelajaran Pendidikan Agama Kristen dengan menggunakan model kooperatif teknik two stay- two stray terjadi peningkatan pada siklus I adalah 70 dan $66 \%$ siswa tuntas belajar. 6 siswa mengalami ketuntasan belajar dengan mendapat nilai $\geq 65$, dan 3 siswa tidak tuntas belajar dengan mendapat nilai $\leq 65$. Pada siklus II terjadi peningkatan nilai rata-rata kelas dari 70 pada siklus I menjadi 78 pada siklus II. Persentase ketuntasan belajar pada siklus II adalah $88 \%$.

\section{PEMBAHASAN}

\section{Pemaknaan Temuan penelitian}

Pembahasan lebih banyak didasarkan pada hasil observasi aktivitas guru, aktivitas siswa dan hasil belajar pada setiap siklusnya. Kegiatan pembelajaran menggunakan model pembelajaran Kooperatif teknik two stay-two stray.

a) Hasil Observasi Keterampilan Guru

\section{1) Siklus I}

Pada saat pra kegiatan pembelajaran.

Pada siklus I pengamat menilai pada saat pra kegiatan pembelajaran, guru membuka pembelajaran dengan memberikan salam, mempersiapkan media, mengajak siswa berdoa dengan baik. Setelah itu guru mengkondisikan kelas dan melakukan presensi dengan baik.

\section{2) Siklus II}

\section{Pra Kegiatan Pembelajaran.}

Pada siklus II pengamat difokuskan pada penilaian pada saat pra
KELAS IV SDN BARATAJAYA SURABAYA kegiatan pembelajaran, guru membuka pembelajaran dengan memberikan salam, mempersiapkan media, mengajak siswa berdoa. Setelah itu guru mengkondisikan kelas dan melakukan presensi.

b) Hasil Observasi Aktivitas Siswa

1) Siklus I

Pada siklus I guru mitra sebagai pengamat, mengamati setiap kejadian, perilaku, perubahan pada siswa. Guru mitra mengamati aktivitas siswa dengan menggunakan lembar obser-vasi aktivitas siswa. Lembar penga-matan aktivitas siswa tersebut, terda-pat delapan komponen yang diamati atau sub indikator. Pada indikator siswa memperhatikan penjelasan guru mendapat kategori sangat baik. Siswa bekerja sama dalam kelompok dan aktif dalam kegiatan kelompok mendapat kategori baik, siswa berani mengemukakan pendapat, serta mengajukan pertanyaan dengan baik. Hal Ini menunjukkan bahwa aktivitas siswa dalam pembelajaran mengguna-kan model kooperatif teknik two stay-two stray meningkat dibanding sebelum dilakukan tindakan. Hal ini sesuai dengan yang dikemukakan oleh Trianto (2007:42), Pembelajaran kooperatif disusun dalam sebuah usaha untuk meningkatkan partisipasi siswa, memfasilitasi siswa dengan pengalaman sikap kepemimpinan dan membuat keputusan dalam kelompok, serta memberikan kesempatan kepada siswa untuk berinteraksi dan belajar bersama-sama siswa yang berbeda latar belakangnya.

Pada kegiatan akhir siswa mengerjakan evaluasi dengan sangat baik. Semua siswa mengerjakan soal evaluasi dengan tertib. Siswa dapat menyelesaikan soal sesuai batas waktu yang ditentukan. Hal ini 
menunjukkan adanya peningkatan dari pembelajaran sebelumnya. Para ahli telah menunjukkan bahwa pembelajaran kooperatif dapat meningkatkan kinerja siswa dalam tugastugas akademik, unggul dalam memahami konsep-konsep yang sulit, dan membantu siswa menumbuhkan kemampuan berpikir kritis (Trianto, 2007:44)

\section{2) Siklus II}

Pada siklus II setiap kejadian, perilaku, perubahan pada siswa terus dipantau peningkatannya. Guru mitra mengamati aktivitas siswa dengan menggunakan lembar observasi aktivitas siswa. Lembar pengamatan aktivitas siswa tersebut, terdapat delapan komponen yang diamati atau sub indikator. Pada indikator siswa memperhatikan penjelasan guru mendapat kategori sangat baik. Beberapa siswa terlibat dalam penggunaan alat peraga sehingga siswa antusias dalam mengikuti pembelajran. Hal tersebut sesuai dengan salah satu kegunaan media pembelajaran yaitu dapat meningkatkan gairah belajar, interaksi lebih langsung antara murid dengan sumber belajar (Daryanto, 2010:5). Siswa bekerjasama dalam kelompok dan aktif dalam kelompok mendapat kategori sangat baik.

Proses pembelajaran siklus II lebih meningkat dibanding pembelajaran pada siklus I. Hal ini terlihat dari peningkatan skor beberapa indikator. Dari pengamatan tesebut sebagian besar siswa mendengarkan penjelasan guru dengan sangat baik, siswa melakukan diskusi sesuai petunjuk guru, kegiatan bertamu dan menerima tamu juga berjalan dengan tertib, tidak ada lagi anak yang menolak bekerja sama dengan teman yang tidak ia sukai. Siswa dapat bekerjasama dengan baik, tidak ragu-ragu lagi dalam mengeluarkan pendapat.
Semua anggota kelompok berpartisipasi aktif dalam kegiatan kelompok.

Pembelajaran kooperatif disusun dalam sebuah usaha untuk meningkat-kan partisipasi siswa, memfasilitasi siswa dengan pengalaman sikap kepe-mimpinan dan membuat keputusan dalam kelompok, serta memberikan kesempatan kepada siswa untuk berinteraksi dan belajar bersamasama siswa yang berbeda latar belakangnya. Pada kegiatan akhir siswa membuat kesimpulan dengan baik.

Dengan meninjau kembali pelajaran yang telah disampaikan dapat dilakukan dengan cara merangkum inti pelajaran atau menarik suatu kesimpulan (Mulyasa, 2006:88). Semua siswa mengerjakan soal evaluasi dengan tertib. Siswa dapat menyelesaikan soal sesuai batas waktu yang ditentukan. Hal ini menunjukkan adanya peningkatan dari pembelajaran sebelumnya. Para ahli telah menunjukkan bahwa pembelajaran kooperatif dapat meningkatkan kinerja siswa dalam tugas-tugas akademik, unggul dalam memahami konsepkonsep yang sulit, dan membantu siswa menumbuhkan kemampuan berpikir kritis (Trianto, 2007:44)

c) Hasil Belajar Siswa

Pada siklus I dengan materi pokok mengapa bergantung kepada Allah? Sub tema: Pendalaman Kisah Ayub mengalami peningkatan hasil belajar dibanding dengan hasil belajar pada data awal sebelum dilakukan tindakan. Hasil belajar siklus I nilai ratarata kelas adalah 70 dengan nilai terendah 40 serta nilai tertinggi sebesar 100. Sedangkan ketuntasan belajar klasikal yang diperoleh siswa adalah $66 \%$ dengan jumlah siswa yang tuntas belajar sebanyak 6 siswa dari 9 siswa. Kriteria tingkat keber- 
PELAKSANAAN PEMBELAJARAN KOOPERATIF TIPE

TWO STAY TWO STRAY UNTUK MENINGKATKAN

HASIL BELAJAR PENDIDIKAN AGAMA KRISTEN

hasilan belajar siswa pada siklus I masuk dalam kategori baik .

Pada siklus II dengan materi pokok mengapa bergantung kepada Allah ? Sub tema : Alasan Hidup bergantung kepada Allah mengalami peningkatan hasil belajar dibanding dengan hasil belajar pada siklus I. Nilai rata-rata hasil belajar siswa siklus II mencapai 78 dengan nilai terendah 50 dannilai tertinggi sebesar 100. Ketuntasan belajar klasikal yang diperoleh sebesar 88\% dengan jumlah siswa yang tuntas belajar sebanyak 8 dari 9 siswa.

Pada siklus II kriteria tingkat keberhasilan belajar masuk dalam kategori baik. Berdasarkan data di atas hasil belajar siswa pada pembelajaran Pendidikan Agama Kristen mengalami peningkatan yang cukup signifikan dari tiap siklusnya. Pada siklus I ketuntasan hasil belajar mencapai $66 \%$ dan pada siklus II mencapai $88 \%$. Kenaikan tersebut mencapai $22 \%$. Pencapaian ketuntasan belajar tersebut telah mencapai indikator keberhasilan yaitu sebesar $75 \%$ siswa mengalami ketuntasan belajar. Hal ini menunjukkan bahwa melalui model pembelajaran Kooperatif Teknik Two stay-two stary dapat meningkatkan kualitas pembelajaran Pendidikan Agama Kristen. Hal tersebut sesuai dengan yang dikemukakan oleh Mulyasa (2004:114) bahwa dari segi hasil, proses pembelajaran dikatakan berhasil apabila terjadi perubahan perilaku yang positif pada diri peserta didik seluruhnya atau setidaktidaknya sebagian besar (75\%). Para ahli telah menunjukkan bahwa pembelajaran kooperatif dapat meningkatkan kinerja siswa dalam tugas-tugas akademik, unggul dalam memahami konsep-konsep yang sulit, dan membantu siswa menumbuhkan kemampuan berpikir kritis (Trianto, 2007:44).

KELAS IV SDN BARATAJAYA SURABAYA

\section{Implikasi Hasil Penelitian}

Dalam penelitian yang telah dilakukan jelas bahwa terjadi adanya peningkatan baik itu berupa hasil belajar, aktivitas guru, maupun aktivitas siswa dalam pembelajaran. Hal ini dapat membuktikan bahwa model pembelajaran kooperatif teknik two stay-two stray dapat meningkatkan kualitas pembelajaran Pendidikan Agama Kristen. Karena model pembelajaran kooperatif teknik two staytwo stray dapat menuntut siswa untuk berkomunikasi, bekerja sama dan bertanggung jawab dalam kelompok karena setiap siswa mempunyai tugas dan tanggung jawab masing-masing. Melalui model pembelajaran kooperatif teknik two stay-two stray memacu guru agar lebih kreatif dalam proses pembelajaran. Kreatif dalam arti aktif dalam membimbing siswanya untuk dapat menyelesaikan permasalahan-permasalahan yang sedang dihadapi. Dengan model pembelajaran kooperatif teknik two stay-two stray aktivitas guru dalam mengajar akan lebih terarah. Hal ini juga sesuai dengan pendapat Isjoni (2009: 92) peran guru dalam pembelajaran adalah sebagai fasilitator diantaranya adalah kemampuan guru dalam menciptakan suasana kelas yang lebih menyenangkan, sehingga dalam pembelajaran siswa tidak akan merasa bosan.

Peningkatan keterampilan bertanya guru, dapat memacu siswa agar lebih kreatif dalam proses pembelajaran, sehingga suasana kelas akan lebih hidup, serta tujuan pembelajaran yang telah dibuat dapat tercapai dengan maksimal. Aktivitas siswa sebelumnya dilakukan tindakan dalam pembe-lajaran Pendidikan Agama Kristen masih kurang, tetapi setelah menggu-nakan model pembelajaran kooperatif teknik two stay-two stray terjadi adanya peningkatan aktivitas 
siswa. Siswa yang sebelumnya tidak aktif dalam pembelajaran (hanya mendengarkan), setelah menggunakan model pembelajaran kooperatif teknik two stay-two stray mereka menjadi aktif dalam proses pembelajaran. Kerja sama yang terjalin antar siswa menjadi lebih erat lagi, karena dalam pembelajaran kooperatif kerjasama sangat diperlukan untuk memecahkan suatu permasalahan yang sedang dihadapi. Model pembelajaran kooperatif teknik two stay-twostray juga menuntun siswa untuk bertanggung jawab sehingga akan melakukan yang terbaik untuk kelompoknya. Diskusi kelompok akan lebih mudah untuk memecahkan permasalahan karena hasil pemikiran dari beberapa ide anak akan lebih kaya dari pada satu anak (Lie: 2010).

Hasil belajar siswa meningkat setelah menggunakan model pembelajaran kooperatif teknik two stay- two stray. Hal ini dikarenakan siswa belajar dengan cara berbagi hasil dan informasi dengan kelompok lain. Sebagaimana dikemukakan oleh Trianto (2007:41) bahwa siswa akan lebih mudah menemukan dan memahami konsep yang sulit jika mereka saling berdiskusi dengan temannya.

\section{SIMPULAN}

Berdasarkan hasil penelitian mengenai peningkatan kualitas pembelajaran Pendidikan Agama Kristen dengan model pembelajaran kooperatif teknik two stay-two stray pada siswa kelas IV SDN Baratajaya Surabaya, maka peneliti menarik kesimpulan sebagai berikut:

1. Penerapan model pembelajaran kooperatif teknik two stay-two stray pada mata pelajaran Pendidikan Agama Kristen dapat meningkatkan keterampilan guru. Hal ini ditunjukkan dari hasil pengamatan pada siklus I rata-rata keterampilan guru 2,8 masuk dalam kategori baik dan siklus II rata-rata aktivitas guru 3,3 dengan kategori sangat baik. Hal ini ditunjukkan dari perilaku pembelajaran guru, menyiapkan kesiapan belajar siswa dan memberikan motivasi pada siswa, Menggali pengetahuan siswa melalui pertanyaan, menyampaikan materi dengan baik, menggunakan media pembelajaran dengan baik, membimbing siswa dalam kegiatan diskusi kelompok, membimbing siswa dalam menyajikan materi dan menggali informasi pada kelompok lain, membimbing siswa dalam mencocokkan temuan mereka dari kelompok lain, membimbing siswa dalam mempresentasikan hasil diskusi, membahas hasil diskusi kelompok, memberikan penguatan dan penghargaan, mengelola pembelajaran, membimbing siswa membuat simpulan, mengadakan evaluasi dan membahas pekerjaan siswa dengan baik.

2. Model pembelajaran kooperatif teknik two stay-two stray dapat meningkatkan aktivitas belajar siswa yang ditunjukkan dengan rata-rata 2,85 masuk dalam kategori baik dan siklus II rata-rata aktivitas siswa 3,22 dengan kategori sangat baik. Hal ini ditunjukkan dari rasa percaya diri siswa dalam menjawab dan mengajukan pertanyaan, siswa dapat mendengarkan penjelasan guru, melakukan diskusi dalam kelompok dengan baik, dapat bekerja sama, mengemukakan pendapat, menyajikan informasi pada kelompok lain, dan menggali informasi pada kelompok lain dengan baik.

3. Model pembelajaran kooperatif teknik two stay-two stray dapat meningkatkan hasil belajar siswa. Hal tersebut ditunjukkan dengan nilai rata-rata pada siklus I:70 dan 
PELAKSANAAN PEMBELAJARAN KOOPERATIF TIPE

TWO STAY TWO STRAY UNTUK MENINGKATKAN

HASIL BELAJAR PENDIDIKAN AGAMA KRISTEN

79 pada siklus II. Ketuntasan belajar siswa pada siklus I adalah $69 \%$ dengan kategori baik dan pada siklus II menjadi $82 \%$ masuk dalam kategori baik. Nilai rata-rata hasil belajar sudah baik karena sebanyak $82 \%$ siswa sudah mengalami ketuntasan belajar sesuai nilai KKM mata pelajaran Pendidikan Agama Kristen SDN Baratajaya yaitu 75. Dengan demikian maka hipotesis dengan menggunakan model pembelajaran kooperatif teknik two stay-two stray kualitas pembelajaran Pendidikan Agama Kristen dapat meningkat telah terbukti kebenarannya.

\section{SARAN}

Berdasarkan kesimpulan, dalam melaksanakan pembelajaran Pendidikan Agama Kristen dengan menggunakan model kooperatif teknik two stray-two stray pada siswa kelas IV SDN Baratajaya Surabaya, maka peneliti memberikan beberapa saran sebagai berikut:

1. Sebagai tindak lanjut dari penelitian ini, maka guru hendaknya menggunakan dan mengembangkan model pembelajaran kooperatif dalam pembelajaran Pendidikan Agama Kristen dengan metode diskusi variatif. Karena dengan kegiatan diskusi yang bervariasi aktivitas siswa meningkat sehingga siswa lebih senang dan tujuan pembelajaran dapat tercapai.

2. Guru hendaknya tidak ragu dalam menggunakan model pembelajaran kooperatif karena alasan diskusi hanya akan membuat kegaduhan, karena sebenarnya dengan pembentukan kelompok yang heterogen diskusi akan berjalan dengan baik.
KELAS IV SDN BARATAJAYA SURABAYA

3. Guru hendaknya membekali para siswa tentang tata cara berdiskusi yang baik.

4. Guru hendaknya menggunakan model pembelajaran kooperatif teknik two stray-two stray dalam pembelajaran Pendidikan Agama Kristen maupun pembelajaran lainnya karena model pembelajaran tersebut terbukti dapat meningkatkan aktivitas guru, aktivitas siswa, dan meningkatkan hasil belajar siswa.

5. Dalam pembelajaran yang dilakukan hendaknya guru menggunakan media pembelajaran untuk memperjelas materi serta memotivasi siswa.

\section{Ucapan Terima Kasih}

Pada kesempatan ini, penulis mengucapkan terima kasih kepada Redaktur yang telah memberikan masukan yang berharga sehingga tulisan dapat diterbitkan di Jurnal Institutio. Terima kasih juga kepada pengurus jurnal Institutio yang telah memberi ruang diskusi

\section{Pustaka Acuan}

Anni, C.T.,dkk. 2007. Psikologi Belajar. Semarang: UPT MKK UNNES.

Arikunto, Suharsimi, dkk. 2009. Penelitian Tindakan Kelas. Jakarta: PT Bumi Aksara.

Sidjabat, B.S. 2000. Strategi pendidikan Kristen.Yogyakarta : Andi.

Daryanto, 2011. Media Pembelajaran. Bandung: Satu Nusa.

Dikti. 2004. Peningkatan Kualitas Pembelajaran. Jakarta: Depdiknas.

E.G Homrighausen, I.H Enklaar, Pendidikan Agama Kristen, Jakarta : BPK Gunung Mulia. 
Hamdani. 2011. Strategi Belajar Mengajar. Bandung: Pustaka Setia.

Hasibuan, J.J. dan Moedjiono. 2010. Proses Belajar Mengajar. Bandung: PT Remaja Rosdakarya.

Huda, Miftahul 2011. Cooperative Learning. Yogyakarta: Pustaka Belajar.

Muhsetyo, G. et al. 2009. Pembelajaran Matematika SD. Jakarta: Universitas Terbuka.

Lie, Anita. 2002. Cooperative Learning : Mempraktikkan Cooperative Learning di ruang-ruang kelas. PT Grasindo.

Nuhamara, Daniel. 2009. Pembimbing Pendidikan Agama Kristen. Bandung : Jurnal Info Media.

Paulus L. Kristianto. 2006. Prinsip \& Praktik Pendidikan Agama Kristen. Yogyakarta : Andi.

Prastowo, Andi. 2011. Bahan Ajar Inovatif. Jogjakarta: Diva Press.

Rifa'i, A.R.C. dan C.T. Anni. 2009. Psikologi Pendidikan. Semarang: UPT MKK UNNES.

Roestiyah. 2012. Pembelajaran Kooperatif Tipe STAD (Student Teams Achievement Division). (Online), http://sarjanaku.com/2011/03 /pembelajarankooperatif-tipestad.html. diakses 21 Maret 2019, pukul 15.48

Rusman. 2010. Model-Model Pembelajaran Mengembangkan Profesinalisme Guru. Jakarta : Raja Grafindo Persada.
Sagala, Syaiful. 2003. Konsep dan Makna Pembelajaran. Bandung : Alfabeta, cet. Ke10, h.3

Sardiman. 2011. Interaksi dan Motivasi Belajar Mengajar. Jakarta: PT Rajagrafindo Persada.

Slameto. 2003. Belajar dan FaktorFaktor Yang Mempengaruhinya. Jakarta: Asdi Mahasatya.

Slavin, R.E. 2010. Cooperative Learning. Bandung: Nusa Media.

Sugiyanto. 2010. Model-model Pembelajaran Inovatif. Surakarta : Yuma Pustaka.

Taufiq. A., dkk. Pendidikan Anak di SD. Jakarta: Universitas Terbuka.

Widodo, A. 2006. Revisi Taksonomi Bloom dan Pengembangan Butir Soal. Buletin Puspendik. 3 (2), 18-29.

Wijayanti, S. 2011. Model Pembelajaran Kooperatif STAD (Student Teams Achievement Division) untuk Meningkatkan Hasil Belajar Matematika pada Siswa Kelas IV SDN 3 Bugel Kedung Jepara : http://lib.unnes.ac.id. diakses 21 Maret 2019, pukul 16.30

https://id.wikipedia.org/wiki/Pembel ajaran_kooperatif mengutip tulisan M. Asrori Ardiansyah, M.Pd pada http://kabarpendidikan.blogsp ot.com/2011/04/tujuanpembelajarankooperatif.html. 